\title{
Information and Analytical Support for Risk Assessment in the Management Accounting System of an Enterprise
}

\author{
Nina llysheva ${ }^{1}$ \\ Elena Karanina ${ }^{2}$ \\ Irina Bykova ${ }^{3}$

\begin{abstract}
1 Ural Federal University named after the first President of Russia B.N. Yeltsin, Russia, Ekaterinburg
${ }^{2}$ Federal Government-financed Educational Institution of Higher Professional Education Vyatka State University (FGEI HPE "VyatSU") Vyatka, Russia

${ }^{3}$ Kotlas branch Admiral Makarov State University of Maritime and Inland Shipping; Correspondence: Irina Bykova
\end{abstract}

\author{
Doi:10.5901/mjss.2015.v6n5s4p348
}

\begin{abstract}
The article describes the process of formation of an information base for risk assessment in the management accounting system of an enterprise. Information provided by the management accounting system at the present stage of development of market relations is becoming increasingly important for effective management and rational decision-making. Development of market relations in Russia and emergence of a large number of private (commercial) domestic and foreign entities have set new accounting tasks. One of them is to provide information to managers for managerial decision-making, and in this context, the need to create a system of internal information-the management accounting-have come to the fore. Traditionally, a management accounting system is understood as an organization's system for collecting, recording, summarizing, and reporting on activities of the organization and its business units for planning, controlling, and managing these activities. The process of gathering information about the activities of the organization includes identifying, classifying, evaluating, and measuring business transactions and other economically significant events with a view to their subsequent reflection in the system of management accounting. In this regard, management accounting can be seen as the basis of the information system of an enterprise.
\end{abstract}

Keywords: management accounting, information, risk, scorecard, risk assessment methodology

\section{Introduction}

In Russia, the definition of management accounting has not yet received more or less clear and unambiguous interpretation in the economic literature. Also, many specialists of enterprises have no consensus about the nature, role, and purpose of management accounting, its place in the enterprise management system, and in the accounting theory.

The dynamism, instability, and unpredictability of the market environment form an information vacuum in various aspects of business management. With the lack of information, the uncertainty occurs, as a result of which an organization becomes more dependent on accidental circumstances with excessive risk. Using the fragmentary defective information, many managers tend to make the right decisions, often attempting to substitute information with intuition. Although professional work requires not replacing, but complementing them with each other.

The information needed to manage organizations, as well as the ability to comprehend and effectively manage information flows are particularly important in the period of formation and development of systems and mechanisms of the information society.

Therefore, the problem of information and analytical support becomes increasingly important and practically significant in business management. The methods that can detect implicit information, fill the gaps in the information, compensate the missing information, generate new data, and eliminate uncertainty and risk seem to be particularly needed.

Most managerial decisions in the financial and economic activity of an enterprise are taken under the conditions of risk due to a number of factors, including the lack of complete information, the presence of conflicting tendencies, the elements of chance, and many others. In this regard, the problem of estimating and accounting risks becomes important as part of the theory and practice of management accounting. In the context of Russia's instability, the risk problem is of 
great importance in justification not only of strategic managerial decisions, but also at the stage of short-term business planning.

It is management accounting that forms such information for managers of different levels within a company in order to force them to take sound managerial decisions. The content of management accounting is determined by the management objectives. They can be changed by the administration depending on the interests and goals assigned to the heads of internal divisions.

\section{Literature Review}

The economic literature has lately been focusing on the formation of management accounting. Significant contribution to the research and development of various aspects of management accounting has been made by Russian scientists and specialists, such as Averchev, Bogatin, Borodin, Valebnikova, Vakhrushina, Karpova, Kerimov, Paly, Sheremet and others. In addition, we can distinguish the works, which deal with information and analytical support of management accounting, authored by Markaryan, Polozova and Bryantseva.

The studies on bookkeeping management accounting held by foreign scientists, including Upchurch, Drury, Kaplan, Norton, Needles, Anderson, Caldwell, Siegel, Horngren and others are of theoretical and practical interest.

The scientific basis of theoretical research in the field of risk management are the works of foreign and domestic scientists who have made a real contribution to the development of the theory and practice of risk management: Kovalev, V., Kovalev, D., Kolchina, etc.

Currently, the term "risk" is widely used in the field of financial activity, information systems, and insurance. The interpretation of risks remains quite free, but the concept of risk in management accounting has been studied insufficiently.

\section{Materials and Methods}

\subsection{The Concept of an Information Base of Risk Analysis in Management Accounting}

The sources of information and analytical support of risk identification are the data of the recording and analysis system of an enterprise, namely, the data of the recording and reporting, analytical, and control subsystems. The risks influence on the operations of companies differently, and they all can contribute to the development of the crisis, but the largest impact on the current financial position is provided by managerial risks, as it is the ineffective management that hinders the effective operation of enterprises in the modern economic conditions (Polozova \& Bryantseva, 2008).

The diverse activities of an enterprise (manufacturing, commercial, financial) are conjugated with some uncertainty of the situation development in the future. Taking any decision related to the choice of an alternative embodiment in a particular situation, an enterprise deals with the uncertainty of the outcome, which is due to the insufficient, missing, or inaccurate information that managers and specialists in the study area have. The uncertainty is generated by the random nature of coincidence, inaccuracy or lack of information.

The operational risk emergence is an objective inevitability and its causes are the uncertainty of production environment, primarily the external one, and the limited nature (finiteness) of the resources of industrial activity and the related reality of their scarcity.

The uncertainty hides the causes and factors of risk that form the situation of risk. Let us consider these concepts.

Risk factors are specific unplanned events that could potentially be realized and lead to deviations from the intended result. Risk factors are the conditions, circumstances in which the risk factors manifest themselves and which lead to negative consequences and to undesirable events. For example, the considerable size of assets that are not being bought or sold (low merchantability of the economy) leads to the fact that the risk compensation is much lower than in highly developed financial markets (Kovalev, 2008).

In modern circumstances, it is the risk-based approach to management accounting that becomes particularly important. In this view, the risk management tasks suggest that managerial accounting, as an information system of the management process, cannot be limited to informing users concerned about the risks associated with the activities of enterprises. It must give an assessment of their potential impact on the property and financial position of the organization and financial performance. In addition, the choice and formation of the organization's accounting policy, presentation and disclosure of information in financial statements also require a comprehensive analysis of the impact of risks.

The main source of information for risk assessment is the information generated in the management accounting system, which includes the whole range of information analysis work of an enterprise, as well as the forms of internal and 
external reporting (Kovalev, 2008).

Information support is a set of information resources (databases), means, methods, and technologies for collecting, processing, storing, and delivering information used in the enterprise's interests. The main task of information in the organization of management is to provide the control subjects (primarily, managers and other participants in the administrative process) with the information necessary for the implementation of specific management functions, particularly, for developing and implementing effective management decisions. To improve the information security of management is the responsibility of the head and the apparatus of the management body (primarily, the information analysis units) (Polozova \& Bryantseva, 2008). Information support is one of the types of support of the management process and the industrial activity itself, along with methodical, psychological, logistical, and other forms of support (Kolchina, 2008).

Despite the diversity of solutions, users, namely top executives, heads of departments, and specialists, need information in order to ensure that their decision is not spontaneous, but reasonable and prudent. Information is the data (knowledge) reducing uncertainty in the related field. Information is the new knowledge, and it does not exist as a finished product, but is generated from the information raw materials, i.e. the data that potentially contain information. The data potentially containing information form the basis of information support of any management process (Polozova \& Bryantseva, 2008).

Thus, the main purpose to form information bases in modern conditions is to provide internal and external users with specific analytical information, the accuracy and timeliness of which contributes to taking effective managerial decisions that directly affect the financial position and stability of the enterprise, the welfare of owners, managers, and also the level of tax revenues.

\subsection{An Information Resource and its Role in Enterprise Management}

To implement the objectives of management of financial and economic activity of an enterprise, the information environment of the enterprise should be used as the fundamental base. Development of managerial decisions and achievement of certain results are very difficult or impossible without adequate information support. On the one hand, the system of defined goals makes certain demands to the array of information relevant to the given business. On the other hand, the peculiar features of the information flow in the enterprise determine the ways of achieving these goals (Polozova \& Bryantseva, 2008).

The role of the information resource (Figure 1) in the management of an industrial enterprise comprises not only the informational support of managerial analysis, but also the new management capabilities. Therefore, one of the most important goals of enterprise management from the perspective of risk assessment is to create a sufficient and efficiently organized flow of information.

Management of financial and economic activity of the enterprise involves making decisions in accordance with many factors of the internal and external micro and macro environment. The effectiveness of decisions taken is influenced by the quality of the information resource in the form of creating and using own and external information field.

Own information field depends entirely on the relation of the enterprise to the information resource, as it is formed based on the internal sources. With regard to an external information field, the task of its formation and use involves overcoming fragmentary nature, unreliability, inconsistency, diversity, redundancy, or deficiency of information coming from various sources and obtained by different ways. 


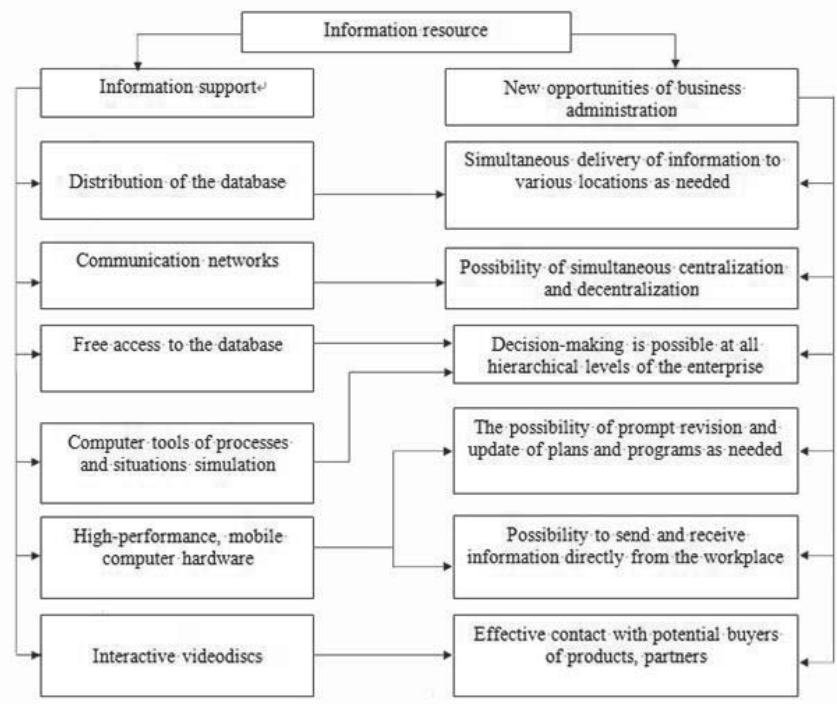

Figure 1. The role of an information resource in the system of management accounting in the circumstances of enterprise's uncertainty

To improve the quality of information resources, it is necessary to create an information strategy meeting the financial and institutional capabilities of the enterprise and the staff, which provides selection of the most reliable sources, organization of information flows, development of technologies to collect, transfer, process, store, and secure the information. Therefore, the database for risk assessment in the management accounting system primarily depends on the system of the used economic information (Kovalev, 2009).

The modern view of the formation of information flows gives grounds to consider an enterprise with all its structural units as a single information analysis field, the total of information flows organized in a certain manner with an "epicenter". It seems more important to form information as a business resource at the current stage (Kovalev, 2009).

An information resource, in this case should be regarded as specific informative data that provide for the solution of an analytical task. Since the data for risk assessment in the management accounting system should contain a wellshaped information policy able to transform information into revenue, there appear the opportunities to use the information resources that require changing the approach to the information itself.

An information base for risk assessment is understood in the management accounting system as the total of data including sufficient and necessary amount of information on all important business lines of the enterprise in order to carry out the procedures of managerial analysis and taking sound managerial decisions based on it (Polozova \& Bryantseva, 2008). Creating a knowledge database requires defining the scope, content, types, and frequency of the analysis; substantiating the technique of the analytical procedures; identifying the influencing factors; establishing a system of indicators and parameters; determining the total demand and the nature of information by local purposes; identifying the sources of information; and checking the quality of the information (Polozova \& Bryantseva, 2008).

Therefore, an information base for risk assessment in the management accounting system is formed under the influence of objective factors, which include the conceptual (methodical and methodological) competence of the subject of analysis (the analyst) as well as the technical and organizational support for information flows.

\subsection{Parameters of the Information Tooling}

There are two basic concepts that determine the quality of information support of managerial decisions: these are the form of information and its suitability for analysis (analyticity).

Since the main form of financial and economic information is a document, the collection and study of documentary information should be supported by:

1) Having full and clear understanding of where and in what form and time frame the required information can be 
obtained from the documents;

2) Providing certain regularity of the documents' circulation. This requires using charts of both internal and external information circulation (integrated document management);

3) Promptly addressing the shortcomings that prevent the formation of an information base-late registration of documents, an excessive amount of fillable copies of documents and signatures to them, lack of responsible persons, insufficient level of mechanical processing, lack of proper organization of document storage, unauthorized access to them, etc.

The level of analytic information is the degree of its compliance with the requirements and objectives of management analysis. In other words, the information must be relevant to the essence of the management decision taken and contribute to its justification in terms of economic benefits.

The greatest amount of information is concentrated in the management accounting subsystem, because management accounting involves not only accounting operations and management reports, but also handling information. Management accounting data are used for retrospective and current analysis, projecting, planning, budget-setting, and alternative calculations.

In addition, to assess the competitive position of an enterprise, it is necessary to analyze the sector as an aggregate of companies competing in the same consumer market. This requires information about the economic characteristics of the sectoral environment, the level of competition in the sector, and the attractiveness of the sector.

All the variety of information used to assess risks is classified by certain attributes (groups) according to the relation to the management system. Identification of input, output, primary, and derived information allows determining the general line of the information base formation.

Input information varies according to the nature and form of the data contained in it. Based on this, the input information is divided into three types: accounting; non-accounted; external (sectoral).

The basis of the accounting information is the data of primarily numeric nature, which fall into one of three categories (Markaryan, Markaryan, \& Gerasimenko, 2009):

1) The data of accounts and tax returns-the primary accounting and tax records, the data coming from the system of financial, managerial, and tax accounting, the forms of financial, managerial, and tax reporting;

2) The data of statistical recording and reporting -the summarized statistical confidential information required for in-house comparisons;

3) The data of operational in-process accounting - production reports together with their completion reports, industrial standards and norms, as well as rationale.

In most cases, the accounting information is presented in standardized forms, both regulated by law (this applies in particular to the forms of financial, tax, and statistical reporting) and developed within organizations (registers of analytical, managerial, and tax accounting, etc.).

These data are subjected to appropriate treatment, only upon which they become information useful for risk assessment in the management accounting system.

The methods of data transformation into managerial (analytical) information can be subdivided into two large groups (Markaryan, Markaryan, \& Gerasimenko, 2009).

The first group comprises standard methods that are applied at regular intervals using standardized reports and other sources of information. The frequency and scope of such preliminary preparation procedures are set by the requirements of individual users or analytical blocks. In modern accounting practice, any computer accounting system has a subsystem of data analysis. There are many special computer programs for standard processing of large volumes of all sorts of data, including economic ones.

The second group includes conversion methods used in rare or unusual situations, such as a correlation and regression analysis, a matrix analysis, analysis of scenarios and situations, etc.

Thus, choosing a particular technique of converting data into information, an analyst can transform it into a methodically conditioned form, which allows further defining the required indicators and parameters.

\section{Results and Discussion}

\subsection{Key Primary Indicators of Information Tooling}

The leading role in providing information to assess the risks in a management accounting system belongs to accounting and reporting, as accounting materials reflect facts and phenomena of economic activity of the enterprise and its results in the most detailed and timely manner. Among the accounting materials, the leading position is held by the data of 
statistical, bookkeeping (financial, managerial), and tax accounting, although in some cases they cannot provide complete and accurate information. The latter necessitates the use of operational reporting and the results of the inprocess control, which assists in timely receipt of necessary information and creates conditions to improve the efficiency of analytical work (Kerimov, Selivanov, \& Minin, 2010).

Operational in-house accounting is largely the basis for the daily management analysis and continuous monitoring of the activities carried out by the enterprise and allows accumulating information in strict accordance with the requirements and objectives of management. The composing of in-house production reporting forms based on operational accounting data can determine what place they will occupy in the information support for risk assessment in the management accounting system, its goals and objectives, as well as information capabilities of official forms of statistical and accounting (financial and management) reporting of the enterprise and their correspondence to the internal managerial needs. Analytical capabilities for official accounting (financial) statements and statistical reporting are presented in Table 1.

We understand the information support in the management accounting system for risk assessment as a total of information resources (also referred to as an information base) and methods of their organization, which are necessary and suitable for the implementation of analytical and managerial procedures that ensure the financial and economic activity of the investigated enterprise. Information base includes a set of data, based on which one can substantiate managerial decisions. In its most general form, we determine an information base as a systematic collection of data used for managerial decision-making. In general, in relation to a particular enterprise, an information base in the management system can be represented as a union of the five large data sets: the data of regulatory and legal nature (the regulatory framework); the data of the bookkeeping system; the data of the tax accounting system; the statistical data, and the nonorganized data. These sets vary in volume, the degree of systematization, generating sources, regularity of updates, and so on (Polozova \& Bryantseva, 2008).

In the management analysis practice of Russian enterprises, other forms of reporting are also used, especially a variety of in-house reporting forms. An analyst can independently take a decision to use certain performance indicators of any specific forms, referring to local analytic tasks of the respective blocks.

Table 1. Information tooling for risk assessment in the management accounting system

\begin{tabular}{|c|c|c|}
\hline \multirow{2}{*}{ Absolute indicator } & \multicolumn{2}{|c|}{ Reporting form } \\
\hline & Statistical & Accounting (financial) \\
\hline Sales volume, thousand rubles & $P-5(m)$ & 2.4 \\
\hline Costs, thousand rubles & $P-5(m), 5-z$ & 2 \\
\hline Retained earnings, thousand rubles & & 1.2 \\
\hline $\begin{array}{l}\text { Gross income, thousand rubles } \\
\text { Gross expenses, thousand rubles }\end{array}$ & - & 2 \\
\hline Number of employees, persons & 1-t,1-enterprise & - \\
\hline Material costs, thousand rubles & 5-z, 6-APK, 9-APK & \\
\hline $\begin{array}{l}\text { Depreciation, thousand rubles } \\
\text { Fixed assets, thousand rubles }\end{array}$ & 11 & Comments to the report \\
\hline $\begin{array}{l}\text { Tangible working assets, thousand rubles } \\
\text { Working assets, thousand rubles }\end{array}$ & - & - \\
\hline Owner's capital, thousand rubles & - & 1.3 \\
\hline $\begin{array}{l}\text { Borrowed capital, thousand rubles } \\
\text { Accounts receivable, thousand rubles } \\
\text { Accounts payable, thousand rubles }\end{array}$ & $P-5(m)$ & 1. Comments to the report \\
\hline $\begin{array}{l}\text { Equity capital, thousand rubles } \\
\text { Personnel's incomes, thousand rubles }\end{array}$ & $\begin{array}{c}\text { 1-enterprise } \\
\text { 1-t,1-enterprise }\end{array}$ & $\begin{array}{c}1.3 \\
\text { Comments to the report }\end{array}$ \\
\hline $\begin{array}{l}\text { Output, ea. } \\
\text { Productive capacity, ea. }\end{array}$ & $\begin{array}{c}\text { 1-in kind, P-5(m), P-1, 6-APK, 9-APK } \\
\text { BM }\end{array}$ & - \\
\hline
\end{tabular}

\subsection{Information Base for Decision-Making}

The presented information base shown in Figure 2 is neither the only possible, nor limiting. Nevertheless, even this representation gives an indication that the information resources in respect of any enterprise are rather extensive. The thoroughness of their organization largely influences on the effectiveness of managerial decisions in respect of the 
investigated enterprise. Each of the blocks shown in the figure is important in its own way.

However, from the perspective of information richness and accessibility, the priority belongs to accounting (financial) statements. Of course, the array of accounting data is more significant. The operational data can generally be configured in virtually unlimited volume. From the perspective of structure, uniformity, and certain predeterminacy, accounting (financial) statements represent the best financial model of an enterprise.

Among all the information systems shown in Figure 2, the accounting (financial) statements are the only relevant array of data, which is invariant by the its main parameters with respect to the stakeholders of the given enterprise, they are persons who have unlimited access to its information base, or persons external to it, and therefore, limited in meeting their information needs.

Management accounting is an integral part of the enterprise management system. The data of well-organized management accounting as an information base of risk assessment allow identifying the areas of the greatest risk, bottlenecks in the enterprise's operation, inefficient or unprofitable products and services, as well as reserves to reduce the unit's prime cost. The content and objectives of management accounting are determined by the management objectives: they can be changed by the administration's decision depending on the interests and goals assigned to the heads of divisions.

At the present stage of development of accounting and management, the formation and implementation of the management accounting system is a complex and time-consuming process consisting of several stages. In general, the implementation of management accounting and risk management in enterprises appears as follows: description of the existing enterprise information system; definition of the requirements for the necessary management information; building a formalized system that can provide managers with the necessary management information; building a management reporting system; building a risk assessment system.

For the successful organization of management accounting, depending on the sectoral characteristics of production and the target, first of all, it is advisable to develop an economically justified classification of costs with account of risks. It will allow identifying and forming: cost centers; responsibility centers; cost drivers. It is also necessary to select the most appropriate option, according to which management accounting will be organized.

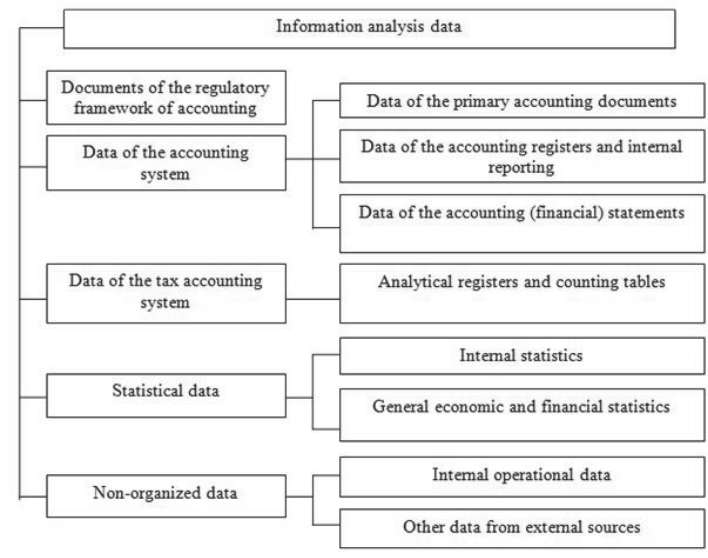

Figure 2. Information base of management accounting of enterprise's risks

Thus, for high-efficiency operation of a modern enterprise, no matter in what the economic sector it may operate, a wellorganized system of management accounting and reporting for managers at various levels is required. On the one hand, this conclusion is obvious and quite banal. On the other hand, a few recommendations have been developed in Russia on the formulation of an effective system of management accounting at enterprises, and the management accounting at them either is in an embryonic state (e.g., in the form of a document flow chart), or is not present at all.

\section{Conclusion}

For risk assessment in the management accounting system, it is necessary to use unbiased information that gives a true 
and fair picture of the enterprise state in order to determine the need for additional sources of financing, and describes the possibility of fulfillment of obligations in full. The results of the analysis can help managers develop a real and most appropriate fiscal policy in the circumstances of economic difficulties.

The peculiar feature of risk assessment in a management accounting system is that it is preventive. On the one hand, already at the beginning of the study, it allows detecting potential or existing problems and selecting the main lines of appropriate in-depth surveys, setting out measures to improve the management strategies and the corresponding action program. On the other hand, upon completion of the entire research program, it is possible to verify the initially put forward diagnostic hypothesis, to formulate the final opinion about the existing management problems, and to specify ways of their solution with account of the peculiar features of the internal and external environment of the enterprise.

The main objective of risk assessment in the management accounting system is the constant monitoring of changes in the state of financial and economic activity of the enterprise, the cause-and-effect analysis, the diagnosis of trends and patterns through implementation of a system of research procedures, identification of weak links and "bottlenecks." Risk assessment in the management accounting system is not a one-time action, but a continuous process, the main objective of which is the timely diagnosis for the object of study and professional expression of opinion about its state.

Finally, it is pertinent to emphasize that information on the activities of an enterprise formed in the management accounting system can be used to optimize it. The analysis and control require establishing the criterion for evaluating their effectiveness, which criterion can be both qualitative and quantitative and characterize the result and/or dynamic parameters of the enterprise operation.

To sum up the above, we can conclude that the information generated in the management accounting is used at all stages of managerial decision-making and is based on the enterprise's development strategy and the interaction between the system of risk management and the management accounting system. We believe that the most effective solution entails providing information support for risk assessment in the system of management accounting, and for this purpose it is necessary to identify, classify, and evaluate the facts of economic life associated with risk, and allocate the objects of management accounting, the cost of which varies under the influence of the risk.

\section{References}

Upchurch, A. (2002). In Y. V. Sokolov, \& I. A. Smirnova (Eds.), Managerial accounting: Principles and practice (Y. V. Sokolov, \& I. A. Smirnova, Trans.). Moscow: Finansy i Statistika.

Bogatin, Y. V. (2009). Management accounting: Information support of rational planning decisions of a company (p. 512). Moscow: Finansy i Statistika.

Vakhrushina, M. A. (2010). Management analysis (p. 399). Moscow: Omega-L.

Drury, C. (2003). Management and Cost Accounting: Study Guide (p. 107). Moscow: UNITY-DANA.

Kaplan, R. (2004). A strategy-oriented organization (p. 416). Moscow: JSC "Olimp-Bisnes".

Kerimov, V. E., Selivanov, P. V., \& Minina, E. V. (2001). The concept of management accounting at the present stage of economic development. Management in Russia and abroad, 4.

Kovalev, V. V. (2009). Basic concepts of the theory of financial management: practical guide (p. 544). Moscow: Prospekt.

Kovalev, G. D. (1999). Basic concepts of innovative management: Textbook for higher education institutions. Moscow: UNITY-DANA.

Kolchina, N. V. (2008). Financial Management: Study Guide (p. 464). Moscow: UNITY-DANA.

Markaryan, E. A., Markaryan, S. E., \& Gerasimenko, G. P. (2009). Management analysis in sectors of economy: Study Guide (p. 304). Moscow: KNORUS.

Needles, B., Anderson, H., \& Caldwell, D. (1997). In Y. V. Sokolov (Ed.), Accounting principles (Y. V. Sokolov, Trans.). Moscow: Finansy i Statistika.

Norton, D. (2010). Balanced Scorecard. Moscow: Olimp-Bisnes.

Paly, V. F. (2003). Organization of management accounting. Moscow: Berator-Press.

Polozova, A. N., \& Bryantseva, L. V. (2008). Management analysis in sectors of economy: Study Guide (p. 336). Moscow: KNORUS.

Khorvat, P. (2000). The Balanced Scorecard as a means of enterprise management. Problemy Teorii i Praktiki Upravleniya, 4, $108-113$.

Horngren, C., Foster, J., \& Datar, S. (2005). Management accounting (10th ed., p. 1008). Saint Petersburg: Piter.

Barnett J., \& Meulbroek, L. (2000). Honeywell Inc. and Integrated Risk Management TN. HBS, Boston.

Bykova, I. V., Karanina, E. V., \& Ilysheva, N. N. (2014). Management Accounting System and the Balanced Scorecard: Reflecting Enterprise Risks. American Journal of Scientific Research, New York, 1, 112-121.

Kloman, H. F. Integrated Risk Assesment. Current Views of Risk Management. Retrieved from http://www.garp.com

Mehr, R. I., \& Hedges, B. A. (2000). Risk Management: Concepts and Applications. Homewood: Irwin.

Meulbroek, L. (2001). A Better Way to Manage Risk. Harvard Business Review.

Nader, J. (2003). The Manager's Concise Guide to Risk. New York: John Wiley \& Sons.

Tarlow, P. E. (2000). Event Risk Management and Safety. New York: John Wiley \& Sons. 